\title{
A safety type of genetically engineered bacterium that degrades chemical pesticides
}

Qin $\mathrm{Li}^{1,2}$, Jing $\mathrm{Li}^{1}$, Ke-Lai Kang ${ }^{1}$ and $\mathrm{Yi}-J u n \mathrm{Wu}^{1 *}$ (]

\begin{abstract}
Chemical pesticides are used widely and their residues are found in the environment. Pesticide pollution has become a global problem. To find an economical, effective and safety way to degrade residues of pesticides in environment, we constructed a genetically engineered bacterium (GEB) having the ability to degrade pesticides, emit green fluorescence and has a containment system by using a dual plasmid expression system. One plasmid contains the genes of enhanced green fluorescent protein (EGFP) and carboxylesterase B1 (CarE B1), which were cloned downstream of lambda $P_{L}$ promoter and expressed constitutively. The gene of CarE B1 encodes an insect-detoxifying enzyme possessing the degradability to organochloride pesticides, organophosphorus pesticides, carbamates, and pyrethoid insecticides. The other is the conditional suicide plasmid for containment system, in which the lethal gene used was the nuclease gene of Serratia marcescens without the leader-coding sequence and was placed downstream of T7 promoter. The GEB has wide prospects of application on cleanup of pesticide residues with its degradability to several pesticides and containment system.
\end{abstract}

Keywords: Genetically engineered bacteria, Pesticide, Degradation, Carboxylesterase B1, Green fluorescent protein, Suicide

\section{Introduction}

Chemical pesticides are used widely in agriculture and forestry to control pests and diseases. Globally 4.6 million tons of chemical pesticides are annually sprayed into the environment, while only $1 \%$ of the sprayed pesticides are effective, and $99 \%$ of the pesticides applied are released to non-target soils, water bodies, and atmosphere, and finally absorbed by almost every organism (Zhang et al. 2011). Besides the sprayed pesticides, large amounts of unused and obsolete pesticides are threatening the environment and public health in many countries too (Karstensen et al. 2006). Pesticides residues have been found in various environment media and livings, and pollution of which has become a persistent

\footnotetext{
*Correspondence: wuyj@ioz.ac.cn

1 Laboratory of Molecular Toxicology, State Key Laboratory for Integrated Management of Pest Insects and Rodents, Institute of Zoology, Chinese Academy of Sciences, 1-5 Beichenxilu Road, Beijing 100101, People's Republic of China

Full list of author information is available at the end of the article
}

environmental problem internationally (Reimer and Prokopy 2012; Akoto et al. 2013; Yurtkuran and Sayg1 2013). The values for the permissible limits of some pesticides have been reported; for example, the reference doses (RfD) of pesticides fenpropathrin and permethrin are 0.025 and $0.05 \mathrm{mg} / \mathrm{kg}$ body weight/day, respectively (USEPA 1987, 1994); the acceptable daily intake (ADI) of pesticide chlorpyrifos is $0.01 \mathrm{mg} / \mathrm{kg}$ body weight/day (USATSDR 1997). Therefore, it is necessary to study the removal or degradation methods of pesticide residues in the environment. Among various technologies studied to clean up residual pesticides, such as chemical oxidation, biotreatment, catalytic treatment, and filtration (Wu et al. 2007), biodegradation was considered an environment friendly approach. Many genetically engineered microorganisms (GEMs) capable of biodegrading pesticides were constructed by recombinant DNA technology (Ingham et al. 1995; Lan et al. 2006; Chungjatupornchai et al. 2011; Khodi et al. 2012). However, the application of the GEMs is usually limited by the risk of genes moving from
Springer Open (c) The Author(s) 2020. This article is licensed under a Creative Commons Attribution 4.0 International License, which permits use, sharing, adaptation, distribution and reproduction in any medium or format, as long as you give appropriate credit to the original author(s) and the source, provide a link to the Creative Commons licence, and indicate if changes were made. The images or other third party material in this article are included in the article's Creative Commons licence, unless indicated otherwise in a credit line to the material. If material is not included in the article's Creative Commons licence and your intended use is not permitted by statutory regulation or exceeds the permitted use, you will need to obtain permission directly from the copyright holder. To view a copy of this licence, visit http://creativeco mmons.org/licenses/by/4.0/. 
GEMs to other organisms and their potential impact on the distribution and growth of the indigenous microbial population. Therefore, it is needed to set up a system to track down the GEMs released into the fields and control the survival of GEMs.

Over the past few decades, several methods such as gene probes, PCR, monoclonal antibodies, bioluminescence, and autofluorescent proteins (AFPs), have been developed to monitor the GEMs (Matheson et al. 1997; Khan et al. 1998; Ramos-González et al. 1992; Ripp et al. 2000; Gory et al. 2001). Of these, AFPs demonstrates the unique superiority; it does not need additional substrates, cofactors, or proteins but $\mathrm{O}_{2}$ for fluorescence (Larrainzar et al. 2005). Green fluorescent protein (GFP) is a natural protein expressed in bioluminescent jellyfish that can emit bright green fluorescence after UV light excitation (Shimomura et al. 1962). Enhanced green fluorescent protein (EGFP) is a red-shifted variant of GFP, which has much stronger fluorescence and was often used in studies (Cormack et al. 1996). To control the survival of GEMs, some active biological containment systems have been designed, often based on lethal genes triggered by specific physical or chemical signals (Knudsen and Karlström 1991; Jensen et al. 1993; Szafranski et al. 1997; Balan and Schenberg 2005), but few of these systems were applied to GEMs whether in experiment or in field.

In this study, we described the construction of a genetically engineered bacterium (GEB) with the ability to degrade pesticides, emit green fluorescence and control itself survival by the co-transformation of two plasmids containing different functional genes and promoters, which provides a safe and effective method of pesticide biodegradation. Among the two plasmids used in this GEB, one was a plasmid carrying the fusion genes of EGFP and carboxylesterase B1 (CarE B1) of Culex pipiens quinquefasciatus, which were placed downstream of lambda $\mathrm{P}_{\mathrm{L}}$ promoters and expressed freely without needing for inducer; the other was the compatible conditional suicide plasmid pDS containing two copies of the lethal nuclease gene of Serratia marcescens without the leader-coding sequence ( $\mathrm{Li}$ and $\mathrm{Wu}$ 2009). The CarE B1 gene encodes an enzyme that confers pesticide resistance (Mouches et al. 1990). Studies indicated that CarE B1 has a strong degradation ability to various pesticides, such as organochloride pesticides, carbamates, pyrethoid insecticides, and organophosphorus pesticides (Vontas et al. 2000; Barata et al. 2004; Nishi et al. 2006).

\section{Materials and methods GEB construction}

The egfp gene without stop codon amplified from pEGFP-N3 (Clontech, Palo Alto, CA, USA) by PCR was cloned into the plasmid pBV220 (kindly gifted by Ms R.
Liu, Tianjin Medical College, China) (Primers used were No. 1 and No. 2 in Table 1) between EcoRI and BamHI to generate plasmid pBV-EGFP. The PCR-amplified fragment of the whole sequence of pBV-EGFP with deletion of the repressor protein cIts 857 gene that is responsible for transcriptional regulation on plasmid pBV220 (Primers used are No. 3 and No. 4 in Table 1) was self-circularized with T4 DNA ligase to form the plasmid pL-EGFP.

The carboxylesterase B1 gene was amplified by using primers No. 5 and No. 6 (see Table 1) from pET-B1, which was obtained from Dr. C. L. Qiao (Institute of Zoology, Chinese Academy of Sciences, Beijing, China). The PCR-amplified B1 gene was then inserted between the BamHI and PstI sites of pL-EGFP to obtain the plasmid pL-EGFP-B1 (Fig. 1b).

The GEB (hereafter, BL21AI-GBS) that can emit green fluorescence, degrade pesticides and commit suicide when induced was constructed by transforming the above plasmid pL-EGFP-B1 and another plasmid pDS sequentially into $E$. coli strain BL21-AI ${ }^{\mathrm{TM}}$ ( $F^{-}$ompT hsd $S_{B}\left(r_{B}^{-} m_{B}^{-}\right)$gal dcm araB::T7RNAP-tetA, Invitrogen) through the calcium chloride procedure (Sambrook and Russell 2001). pDS was a conditional suicide plasmid induced by arabinose, containing two suicide cassettes designed with the nuclease gene of Serratia marcescens (Li and Wu 2009). BL21AI-GBS's green fluorescence and ability to degrade pesticides do not require induction, but the cell suicide containment system must be activated by adding arabinose to the culture medium.

\section{Detection of the intensity of fluorescence and GEB growth curve}

Cultures incubated overnight were transferred into (2\%) liquid Luria-Bertani (LB) medium containing ampicillin $\left(50 \mu \mathrm{g} \mathrm{ml}^{-1}\right)$ and kanamycin $\left(50 \mu \mathrm{g} \mathrm{ml}^{-1}\right)$, and then incubated at $28{ }^{\circ} \mathrm{C}$ in a shaker. When optical density $\left(\mathrm{OD}_{600}\right)$ reached the mid-growth phase (0.5-0.8), cultures were divided into two parts. $0.01 \%$ arabinose (final concentration, wt/vol) was added into one part to turn

\section{Table 1 Primers used in this study}

\begin{tabular}{lll}
\hline No & $\begin{array}{l}\text { Restriction } \\
\text { enzymes }\end{array}$ & Sequence $\left(\mathbf{5}^{\mathbf{\prime}} \boldsymbol{\rightarrow} \mathbf{3}^{\prime}\right)^{\mathbf{b}}$ \\
\hline 1 & ECoRl & GGGAATTCATGGTGAGCAAGGGCGAGGAGCT \\
2 & BamHI & TTGGATCCCTTGTACAGCTCGTCCATGCCGAG \\
3 & Sacl & TTCGAGCTCCGTGCGTGTTGACTATTTTACCT \\
4 & Xbal & GCTCTAGATCGGCAAGGTGTTCTGGTC \\
5 & Bg/ll & GAAGATCTATGAGTTTGGAAAGCTTAACCGT \\
6 & Pstl & AACTGCAGTCAAAACAGCTCATCATTCACGTACAT \\
a & Restriction enzyme that can digest the sequences underlined \\
b Underlined sequences are restriction sites
\end{tabular}




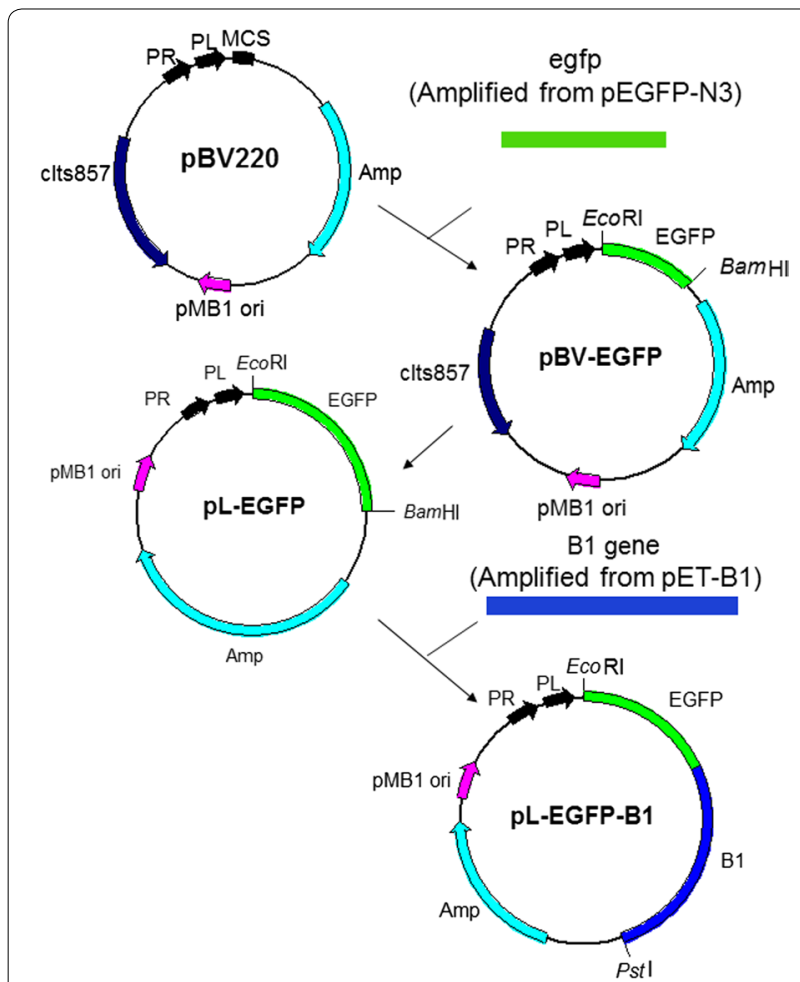

Fig. 1 Construction map of the recombinant plasmid. Construction map of the plasmid pL-EGFP-B1. The egfp gene without the stop codon was cloned into the plasmid pBV220 to construct the plasmid pBV-EGFP. The entire sequence of pBV-EGFP except the clts857 gene was amplified by PCR and self-circularized to generate the plasmid pL-EGFP. Then, the B1 gene was inserted to generate the final plasmid pL-EGFP-B1. $P_{R}$ and $P_{L}$ indicate the lambda $P_{R}$ promoter and $P_{L}$ promoter, respectively. MCS is the multiple cloning sites and ori is the origin

on the cell suicide containment system whereas nothing was added to the other which was used as a control. Both parts continued to be incubated at $28^{\circ} \mathrm{C}$ for $15 \mathrm{~h}$, during which samples were taken every $1.5 \mathrm{~h}$. A Beckman DU800 spectrophotometer (Foulerton, MN, USA) and a Hitachi F-4500 fluorescence spectrophotometer (Hitachi, Tokyo, Japan) (excitation wavelength: $488 \mathrm{~nm}$; emission wavelength: $509 \mathrm{~nm}$; bandwidth: $5 \mathrm{~nm}$ ), were used to detect the $\mathrm{OD}_{600}$ and fluorescence of samples respectively.

A plate experiment was performed with the 15-h samples as follows: Samples were diluted with nonselective $\mathrm{LB}$ medium till their $\mathrm{OD}_{600}$ reached 0.200 , then diluted 200 times with the same medium. Finally, one hundred and fifty microliters $(150 \mu \mathrm{l})$ of the secondary dilution was spread on different selective plates (LB plate containing $50 \mu \mathrm{g}$ ampicillin $\mathrm{ml}^{-1}, 50 \mu \mathrm{g}$ kanamycin $\mathrm{ml}^{-1}$, or a combination of $50 \mu \mathrm{g}$ ampicillin $\mathrm{ml}^{-1}$ and $50 \mu \mathrm{g}$ kanamycin $\mathrm{ml}^{-1}$ ). After incubation at $28{ }^{\circ} \mathrm{C}$ for $16-24 \mathrm{~h}$, the number of colonies on the plates were counted, and the fluorescence of colonies were detected by using a Leitz DMIRB microscope (Leica, Germany).

\section{Preparation of cell protein}

Cells were harvested by centrifugation at $12,000 \times g$ for $30 \mathrm{~s}$ at $4{ }^{\circ} \mathrm{C}$, washed with $10 \mathrm{mM}$ phosphate-buffered saline (PBS) ( $\mathrm{pH} 7.0)$, and resuspended completely in the same buffer (200 $\mu \mathrm{l}$ vs. starting volume of $1 \mathrm{ml}$ culture), then the lysozyme of $50 \mathrm{mg} / \mathrm{mL}$ and $10 \%$ Triton X-100 were respectively added in one percent volume. The suspension was incubated at $30^{\circ} \mathrm{C}$ for $15 \mathrm{~min}$, then sonicated on ice until cells break up. The resultant mixture was the total cell protein (TCP), which was then centrifuged at $10,000 \mathrm{~g}$ for $10 \mathrm{~min}$ and the supernatant was retained. The supernatant was the crude protein solution (CPS), which was used as the source of the protein to determine the enzymatic activity. Protein concentration was measured using the Bradford method with bovine serum albumin (BSA) as the standard (Bradford 1976).

\section{Western blotting analysis}

Equal amounts of TCP $(10 \mu \mathrm{g})$ were mixed with SDSPAGE loading buffer and boiled at $100{ }^{\circ} \mathrm{C}$ for $3 \mathrm{~min} .10 \%$ SDS-polyacrylamide gels was used to separate the protein samples. After electrophoresis, proteins were blotted onto a Hybond enhanced chemiluminescence (ECL) nitrocellulose membrane (Amersham, Arlington Heights, IL, USA) using the wet transblotting method. The primary antibody was anti-GFP monoclonal antibody (Clontech) and the secondary antibody was a horseradish peroxidase-conjugated anti-mouse IgG (Sigma, St Louis, MO, USA). When used, their dilution ratios were 1:1000 and 1:5000 dilution, respectively. The Western blots were detected by using standard ECL reagents (Pierce, Rockford, IL, USA) and imaged by using a ChemiDoc XRS system (Bio-Rad, Hercules, CA, USA).

\section{Carboxylesterase (CarE) activity assay}

Carboxylesterase (CarE) activity in CPS was assayed using $\beta$-naphthyl acetate ( $\beta$-NA) as a substrate (Asperen 1962). About $25 \mu \mathrm{l}$ of $10 \mathrm{mM} \beta$-NA was added into 1 , $972.5 \mu \mathrm{l}$ of $200 \mathrm{mM}$ PBS and $2.5 \mu \mathrm{l} \mathrm{CPS}$ and then incubated at $37{ }^{\circ} \mathrm{C}$ for $5 \mathrm{~min}$. The reaction was stopped by adding of $500 \mu \mathrm{l}$ of stop solution (mixture of $1 \%$ Fast Blue $\mathrm{B}$ and 5\% SDS, 2:5, v/v) and the absorbance was detected at $550 \mathrm{~nm}$. Activities are showed as nmol $\beta$-naphthol liberated per min per $\mu \mathrm{g}$ protein.

\section{Determination of degradation of organophosphorus pesticide}

In this study, we chose chlorpyrifos as the tested organophosphorus pesticide since chlorpyrifos has been a widely used pesticide, which is a substitute for highly 
toxic organophosphorus pesticides that had been banned in China and other countries. Chlorpyrifos has a characteristic absorption peak at $293 \mathrm{~nm}$, and the residue of chlorpyrifos in solution can be determined by ultraviolet spectrophotometry. Five hundred microliters $(0.5 \mathrm{~mL})$ of CPS and $0.5 \mathrm{~mL}$ of $1 \mathrm{mg} / \mathrm{mL}$ chlorpyrifos (dissolved in acetone) were added into the test tube containing $4 \mathrm{~mL}$ of $0.05 \mathrm{M}$ Tris- $\mathrm{HCl}$ buffer ( $\mathrm{pH}$ 7.2). After mixing, $2 \mathrm{~mL}$ of the mixture was taken out, and $0.5 \mathrm{~mL}$ of $50 \%$ trichloroacetic acid (TCA) as a stop solution was added, then mixed, and temporarily stored in a refrigerator at $4{ }^{\circ} \mathrm{C}$, which was used as a 0 -h sample. After the remaining mixture reacted in a water bath at $37^{\circ} \mathrm{C}$ for $5 \mathrm{~h}, 2 \mathrm{~mL}$ of the reaction solution was taken up, and $0.5 \mathrm{~mL}$ of $50 \%$ TCA was added thereto, which was a 5 -h sample. Two milliliters $(2 \mathrm{~mL})$ of petroleum ether was separately added to the $0-\mathrm{h}$ and 5 -h samples for extraction, and the upper organic phase was taken for measurement. The $\mathrm{OD}_{293}$ was measured by a spectrophotometer, and the chlorpyrifos content in the samples were calculated according to the standard curve. The degradation rate of chlorpyrifos was expressed by the percentage of residual chlorpyrifos after $5 \mathrm{~h}$ of reaction.

\section{Determination of degradation of pyrethroid pesticides}

The pyrethroid pesticides fenpropathrin, permethrin, and tetramethrin were used to study the degradation activity of pyrethroid pesticides by BL21AI-GBS, and the degradation rate was determined by the residual amount of pesticides after $5-\mathrm{h}$ reaction. The degradation reaction systems were set as follows: $0.5 \mathrm{~mL}$ of CPS and $0.5 \mathrm{~mL}$ of $1 \mathrm{mg} / \mathrm{mL}$ pesticide (dissolved in acetone) were added into the test tube containing $4 \mathrm{~mL}$ of $0.05 \mathrm{M}$ Tris- $\mathrm{HCl}$ buffer ( $\mathrm{pH}$ 7.2). After mixing, $2 \mathrm{~mL}$ of the mixture was taken out, and $0.5 \mathrm{~mL}$ of $50 \%$ TCA was added as a reaction terminator, mixed, and temporarily stored in a refrigerator at $4{ }^{\circ} \mathrm{C}$, which was used as a "0-h sample". After the remaining mixture reacted in a water bath at $37^{\circ} \mathrm{C}$ for $5 \mathrm{~h}, 2 \mathrm{~mL}$ of the reaction solution was taken up, and $0.5 \mathrm{~mL}$ of $50 \%$ TCA was added thereto, which was used as a " 5 -h sample". Two milliliters $(2 \mathrm{~mL})$ of $\mathrm{n}$-hexane was separately added to the 0 -h sample and 5-h sample for extraction, and the upper organic phase was taken for measurement. The pyrethroid pesticides in the extracting solutions were analyzed by an Agilent 6890 gas chromatograph-5976 N mass selective detector (GC-MSD) system (Agilent Technologies Inc., Santa Clara, CA, USA) equipped with a DB-5 capillary column $(30 \mathrm{~m} \times 0.25 \mathrm{~mm} \times 0.25 \mu \mathrm{m}$, J \& W Scientific, CA, USA). The carrier gas was helium at a constant flow rate of $1.2 \mathrm{~mL} \mathrm{~min}^{-1}$. The column temperature was programmed to rise from 100 to $200{ }^{\circ} \mathrm{C}$ at $16{ }^{\circ} \mathrm{C} \mathrm{min}^{-1}$ and then to $300{ }^{\circ} \mathrm{C}$ at $8{ }^{\circ} \mathrm{C} \mathrm{min}-1$ and held for $5 \mathrm{~min}$ at $300{ }^{\circ} \mathrm{C}$.
One microliter $(1.0 \mu \mathrm{L})$ of the sample was injected in splitless mode. The injection port, GC-MS interface, and ion source temperatures were maintained at 250,300 , and $200{ }^{\circ} \mathrm{C}$, respectively. The ionization was carried out in the electron impact mode at $70 \mathrm{eV}$ and the data were acquired under selected ion monitoring (SIM) mode.

\section{Determination of degradation of organochloride pesticide} Plifenate, an organochloride insecticide was used to study the degradation activity of organochloride pesticide by the GEB, and the degradation rate was determined by the residual amount of pesticides after 2 -h reaction. The reaction buffer was $0.01 \mathrm{M}$ potassium phosphate buffer $(\mathrm{pH}$ 7.5 ), and the reaction volume was set to $4 \mathrm{~mL}$, including $500 \mu \mathrm{g}$ of TCP of BL21AI-GBS and $10 \mu \mathrm{g}$ of plifenate. After mixing, $0.5 \mathrm{~mL}$ of the reaction mixture was taken out, which was used as a " 0 -h sample". The remaining mixture reacted in a water bath at $30^{\circ} \mathrm{C}$ for $2 \mathrm{~h}$, and then $0.5 \mathrm{~mL}$ of the reaction solution was taken up, which was used as a "2-h sample". $0.5 \mathrm{~mL}$ of n-hexane was separately added to the 0 -h sample and 2-h sample for extraction. Every sample was extracted twice, and the mixture of two extracts (the upper organic phase) was used as the test sample. The amount of plifenate in the extracting solutions was analyzed by an Agilent 7890A gas chromatograph system with electron capture detector (Agilent Technologies Inc., Santa Clara, CA, USA), equipped with a capillary column HP-1701 $(60 \mathrm{~m} \times 0.25 \mathrm{~mm} \times 0.25 \mu \mathrm{m})$. The carrier gas was high-purity helium. Both the injection port temperature and the detector temperature were $300{ }^{\circ} \mathrm{C}$. The initial column temperature was set at $50{ }^{\circ} \mathrm{C}$ for $1 \mathrm{~min}$, and then increase to $190{ }^{\circ} \mathrm{C}$ at a rate of $10{ }^{\circ} \mathrm{C} \mathrm{min}-1$, and then continued to $220^{\circ} \mathrm{C}$ at a rate of $2{ }^{\circ} \mathrm{C} \mathrm{min}-1$ and hold at this temperature for $5 \mathrm{~min}$.

\section{Results}

Growth curves and change in intensity of fluorescence

Growth curves indicated that cells containing the pDS plasmid (BL21AI-GBS and cells harboring the pDS plasmid alone, hereafter BL21AI-DS) multiplied slightly slower than the controls after the addition of arabinose, and eventually stopping completely about $5 \mathrm{~h}$ later of induction (Fig. 2a). To verify the effectiveness of the suicide mechanism, samples collected at $15 \mathrm{~h}$ intervals were spread on different selective plates. No colonies of induced BL21AI-GBS cells were found on plates containing kanamycin, or both kanamycin and ampicillin, while $322 \pm 18$ colonies were found on the plate containing ampicillin. The plates with BL21AI-GBS cultures that had not been induced were densely covered by more than 20,000 colonies (data not shown).

After induction, the intensity of fluorescence of uninduced BL21AI-GBS cultures, and that of cells containing 


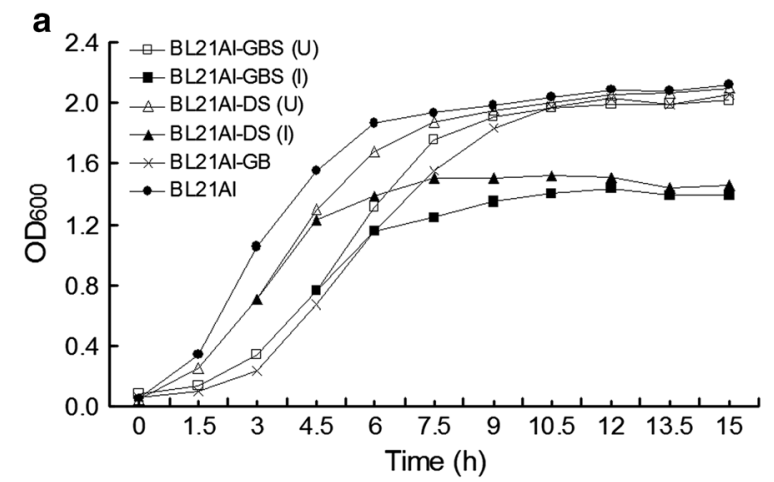

b

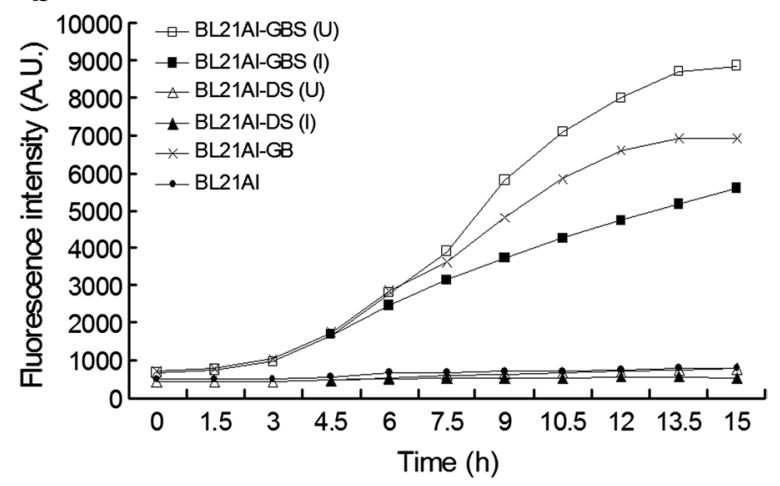

Fig. 2 Growth curves (a) and fluorescence intensity (b) of BL21Al-GBS, BL21AI-DS, BL21Al-GB, and E. coli BL21 AI ${ }^{\mathrm{TM}}$. Cultures of BL21Al-GBS and BL21AI-DS were divided into two parts when their optical density $\left(\mathrm{OD}_{600}\right)$ was in the range of $0.500-0.800$. One part was induced by adding $0.01 \%$ arabinose, while the other used as a non-induced control. The optical density and intensity of fluorescence of all cultures were detected every $1.5 \mathrm{~h}$ with a spectrophotometer and a fluorescence spectrophotometer, respectively. $U$ and $I$ indicate the uninduced culture and induced culture, respectively

pL-EGFP-B1 (hereafter, BL21AI-GB), increased rapidly with the prolongation of culture time, while the fluorescence of BL21AI-GBS cultures increased more slowly; almost exactly matching its post-induction growth curves (Fig. 2b). Cells without the pL-EGFP-B1 plasmid showed only a basal level of fluorescence during the whole experiment process.

When a fluorescent microscope was used to detect bacterial colonies; strong green fluorescence was detected from colonies of BL21AI-GBS and BL21AI-GB (Fig. 3a, b). Green fluorescence was also detectable in these colonies with the naked eye in daylight (Fig. 3c, d). The Western blot test confirmed the existence of the fusion protein EGFP-B1 in BL21AI-GBS and BL21AI-GB (Fig. 4).

\section{Carboxylesterase (CarE) activity}

$\beta$-naphthyl acetate could be used as a substrate to determine the activity of CarE, because the later could degrade $\beta$-naphthyl acetate to $\beta$-naphthol, which could be estimated by a sensitive colorimetric method. The result showed that CarE activities of the CPS of BL21AI-GBS and BL21AI-GB were $0.634 \pm 0.030$ and $0.493 \pm 0.020 \mathrm{nmol} \beta$-naphthol produced per min per $\mu \mathrm{g}$ protein, respectively. However, the basal activity of CarE in E. coli BL21AI ${ }^{\mathrm{TM}}$ was only $0.082 \pm 0.003 \mathrm{nmol}$ $\beta$-naphthol produced per min per $\mu$ g protein (Table 2 ).

\section{Degradation of pesticides}

The results of pesticide degradation experiments showed that the residual percentages of the three pyrethroid pesticides (fenpropathrin, permethrin, and tetramethrin) and the organochlorine pesticide plifenate after the degradation by the GEB BL21AI-GBS were significantly different from those of the control bacteria $E$. coli $\mathrm{BL} 21 \mathrm{AI}^{\mathrm{TM}}$, and there was no difference in the residual percentages of the organophosphorus pesticide chlorpyrifos between BL21AI-GBS and E. coli $\mathrm{BL} 21 \mathrm{AI}^{\mathrm{TM}}$,both were close to $100 \%$ (Table 3). The initial and final concentrations of the pesticides used in the degradation experiment were summarized in Additional file 1: Table S1. The 5-h residual percentages of the three pyrethroid pesticides of BL21AI-GBS were below $50 \%$ and significantly different from that of the control $(P<0.05)$, while that of the control was all about $100 \%$. Among them, the residual percentages of
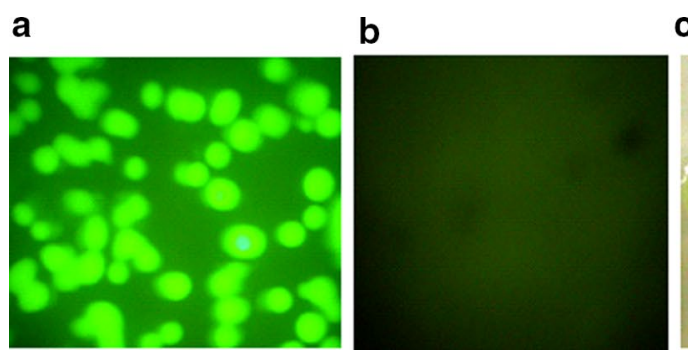

c

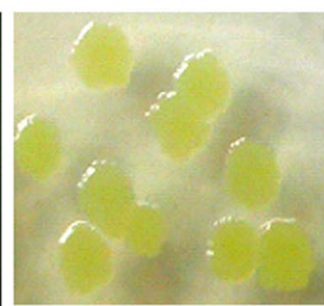

d

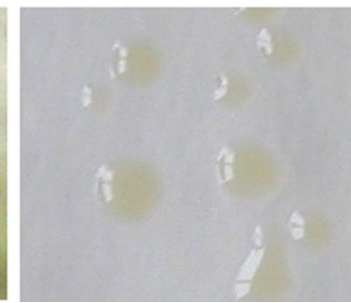

Fig. 3 Images of BL21AI-GBS. $\mathbf{a}$, b Colonies of BL21AI-GBS (a) and E. coli BL21AI ${ }^{\top M}$ (b) on LB agar plates photographed by a fluorescent microscope (magnification: $10 \times 4$ ); $\mathbf{c}$, d colonies of BL21AI-GBS (c) and E. coli BL21 Al ${ }^{\mathrm{TM}}(\mathbf{d})$ on LB agar plates photographed directly in daylight 


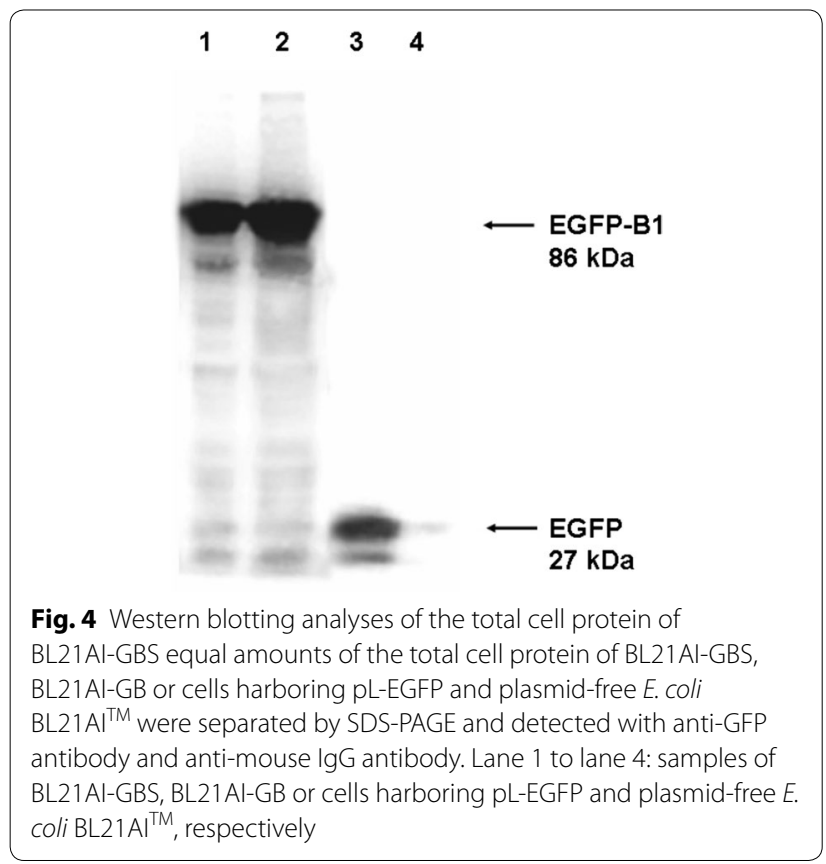

Table 2 Carboxylesterase activity of the CPS of BL21AIGBS, BL21AI-GB, and E. coli BL21 AI ${ }^{\mathrm{TM}}$

\begin{tabular}{ll}
\hline Samples & $\begin{array}{l}\text { Nanomoles of } \beta \text {-naphthol } \\
\text { liberated per min per microgram } \\
\text { of protein }\end{array}$ \\
\hline BL21Al-GBS & $0.634 \pm 0.030$ \\
BL21Al-GB & $0.493 \pm 0.020$ \\
E. coli BL21AI & $0.082 \pm 0.003$ \\
\hline
\end{tabular}

CPS crude protein solution

Table 3 Degradation of pesticides by the GEB BL21 AI-GBS

\begin{tabular}{llc}
\hline Pesticides & \multicolumn{2}{l}{ Percentage of residual pesticide (\%) } \\
\cline { 2 - 3 } & BL21AI-GBS & E. coli BL21 AI $^{\mathbf{T M}}$ \\
\hline Chlorpyrifos & $98.83 \pm 7.40$ & $100.48 \pm 5.39$ \\
Fenpropathrin & $17.80 \pm 3.00^{*}$ & $100.75 \pm 18.92$ \\
Permethrin & $15.04 \pm 2.64^{*}$ & $106.55 \pm 21.73$ \\
Tetramethrin & $47.00 \pm 1.99^{*}$ & $108.56 \pm 21.37$ \\
Plifenate & $73.23 \pm 7.91^{*}$ & $94.58 \pm 1.80$ \\
\hline
\end{tabular}

${ }^{*} \mathrm{P}<0.05$, compared with that of control bacteria E. coli BL21AI ${ }^{\mathrm{TM}}$

fenpropathrin and permethrin were less than $20 \%$ (18\% and $15 \%$, respectively). And the 2 -h residual percentage of the GEB for the organochlorine pesticide was about $75 \%$, while that of control was about $95 \%$, and there was also a statistical difference between them $(P<0.05)$ (Table 3; Additional file 1: Table S1).

\section{Discussion}

As we know, expression of heterologous protein may increase burden on host cells. The gene of fusion protein EGFP-B1 was put downstream of the lambda $\mathrm{P}_{\mathrm{L}}$ promoter in the recombinant plasmid, and expressed freely in the GEB because of the absence of the lambda cIts857 repressor. The growth rate of cells containing the plasmid pL-EGFP-B1 (BL21AI-GBS, BL21AI-GB) was slower than others (Fig. 2a), this indicated that the constitutive expression of heterologous protein EGFP-B1 might increase burden on the growth of the GEB. Fortunately, the growth burden did not affect the desired function of the GEB. When inducer was added to trigger the suicide mechanism in the GEB, the growth of BL21AI-GBS and BL21AI-DS decreased significantly and almost stopped about $5 \mathrm{~h}$ later of induction.

The results of plate experiment further verified the effectiveness of suicide mechanism. However, the colonies found on plates containing ampicillin but none on plates containing kanamycin indicated that the suicide plasmid pDS was lost in some cells of BL21AI-GBS during incubation, because the resistance of ampicillin and kanamycin was carried by plasmid pL-EGFP-B1 and pDS respectively. To avoid the plasmid-loss, it may be a better way to place the suicide mechanism on the chromosome of host cell or adopt other ways to increase plasmid stability.

The results of fluorescence detection, including detection of fluorescence spectrophotometer, fluorescent microscope and observation by the naked eye in daylight, indicated that the expression of EGFP-B1 endowed BL21AI-GBS with green fluorescence, which could be used to monitor the dispersion and cell density of the GEB (Leff and Leff 1996; Bastos et al. 2001) and indicate the enzyme activity to some extent (Wu et al. 2000).

The results of the enzyme activity assays showed that CPS of the cells containing plasmid pL-EGFP-B1 (BL21AI-GBS, BL21AI-GB) has esterase activity. Notably, the activity of BL21AI-GBS is higher than that of BL21AI-GB. The reason for the difference of activity may be the difference in expression amount or existing form of EGFP-B1 expressed in BL21AI-GBS and BL21AI-GB. Anyway, co-transformation with pDS not only had no adverse effect but also have positive influences on the esterase activity and fluorescence intensity of BL21AI-GBS.

In order to further verify the degradation effect of BL21AI-GBS on pesticides, we chose three types of pesticides organophosphorus pesticide, pyrethroid pesticides and organochloride pesticide to do the pesticide degradation experiments. The results showed that there was no significant difference between BL21AI-GBS and control bacteria in the residual percentage of the 
organophosphorus pesticide chlorpyrifos after 5-h degradation reaction, but the percentages of residues of the three pyrethroid pesticides fenpropathrin, permethrin and tetramethrin, and the organochloride pesticide plifenate by BL21AI-GBS were significantly lower than that of the control bacteria. And under the same conditions, the residual percentages of permethrin and fenpropathrin were only one-third or less than half of that of tetramethrin, respectively. These results suggested that BL21AI-GBS may have no obvious degradation effect on organophosphorus pesticides under the experimental conditions, but have significant degradation effect on the pyrethroid pesticides and the organochloride pesticide. In addition, the results indicated that the GEB had different degradation effect on different pyrethroid pesticides; the effect on permethrin and fenpropathrin was better than that on tetramethrin. Some researches on GEB of pesticide degradation have been reported, but few of them involve a containment system in the GEB. The coexistence of the containment system and green fluorescence labelling in the GEB generated in our study is more conducive to reduce the environmental risk and improve the possibility of practical application.

In summary, the GEB generated possesses the ability to degrade pesticides, emit green fluorescence and has a containment system. The GEB could be used to degrade various pesticides, easily monitored through green fluorescence when used in practice, and commit suicide when required. Compared with our previous study, the BL21AI-GBS in this study has much broader scope of application, the enzyme activity endowed by EGFP-B1 could be used to degrade various pesticides, including pyrethroid insecticides and organochloride pesticides.

\section{Supplementary information}

Supplementary information accompanies this paper at https://doi. org/10.1186/s13568-020-00967-y.

Additional file 1: Table S1. The concentrations of the pesticides used in the experiment for the bacteria BL21Al-GBS on pesticide degradation.

\section{Acknowledgements}

We thank Prof. C. L. Qiao for providing the plasmid pET-B1, Ms. R. Liu for the plasmid pBV220.

\section{Authors' contributions}

QL and YJW designed the experiments. QL, JL and KLK conducted the experiments. QL and YJW wrote this manuscript. All authors read and approved the final manuscript.

\section{Funding}

This research was supported in part by the grants from the National Natural Science Foundation of China (No. 31672366) and the State Key Laboratory of Integrated Management of Pest Insects and Rodents (Chinese IPM1718).

\section{Availability of data and materials}

All data obtained have been included into the manuscript.

\section{Ethics approval and consent to participate}

This article does not contain any studies with human participants or animals performed by any of the authors.

\section{Consent for publication}

All authors agree to submit this manuscript to AMB Express for publication.

\section{Competing interests}

The authors declare that they have no competing interests.

\section{Author details \\ ${ }^{1}$ Laboratory of Molecular Toxicology, State Key Laboratory for Integrated Man- agement of Pest Insects and Rodents, Institute of Zoology, Chinese Academy of Sciences, 1-5 Beichenxilu Road, Beijing 100101, People's Republic of China. ${ }^{2}$ Environmental Standards Institute, Chinese Research Academy of Environ- mental Sciences, Beijing 100012, People's Republic of China.}

Received: 8 November 2019 Accepted: 3 February 2020

Published online: 18 February 2020

\section{References}

Akoto O, Andoh H, Darko G, Eshun K, Osei-Fosu P (2013) Health risk assessment of pesticides residue in maize and cowpea from Ejura, Ghana. Chemosphere 92:67-73

Asperen KV (1962) A study of house fly esterase by means of a sensitive colorimetric method. J Insect Physiol 8:401-416

Balan A, Schenberg ACG (2005) A conditional suicide system for Saccharomyces cerevisiae relying on the intracellular production of the Serratia marcescens nuclease. Yeast 22(3):203-212

Barata C, Solayan A, Porte C (2004) Role of B-esterases in assessing toxicity of organophosphorus (chlorpyrifos, malathion) and carbamate (carbofuran) pesticides to Daphnia magna. Aquat Toxicol 66(2):125-139

Bastos AE, Cassidy MB, Trevors JT, Lee H, Rossi A (2001) Introduction of green fluorescent protein gene into phenol-degrading Alcaligenes faecalis cells and their monitoring in phenol-contaminated soil. Appl Microbiol Biotechnol 56:255-260

Bradford MM (1976) A rapid and sensitive method for the quantitation of microgram quantities of protein utilizing the principle of protein-dye binding. Anal Biochem 72:248-254

Chungjatupornchai W, Kamlangdee A, Fa-Aroonsawat S (2011) Display of organophosphorus hydrolase on the cyanobacterial cell surface using synechococcus outer membrane protein a as an anchoring motif. Appl Biochem Biotechnol 164(7):1048-1057

Cormack BP, Valdivia RH, Falkow S (1996) FACS-optimized mutants of the green fluorescent protein (GFP). Gene 173(1):33-38

Gory L, Montel MC, Zagorec M (2001) Use of green fluorescent protein to monitor Lactobacillus sakei in fermented meat products. FEMS Microbiol Lett 194(2):127-133

Ingham ER, Doyle JD, Hendricks CW (1995) Assessing interactions between the soil foodweb and a strain of Pseudomonas putida genetically engineered to degrade 2, 4-D. Appl Soil Ecol 2(4):263-274

Jensen LB, Ramos JL, Kaneva Z, Molin S (1993) A substrate dependent biological containment system for Pseudomonas putida based on the Escherichia coligef gene. Appl Environ Microbiol 59(11):3713-3717

Karstensen KH, Kinh NK, Thang LB, Viet PH, Tuan ND, Toi DT, Hung NH, Quan TM, Hanh LD, Thang DH (2006) Environmentally sound destruction of obsolete pesticides in developing countries using cement kilns. Environ Sci Policy 9(6):577-586

Khan AA, Jones RA, Cerniglia CE (1998) Rapid method for the detection of genetically engineered microorganisms by polymerase chain reaction from soil and sediments. J Ind Microbiol Biotechnol 20(2):90-94

Khodi S, Latifi AM, Saadati M, Mirzaei M, Aghamollaei H (2012) Surface display of organophosphorus hydrolase on E. coli using N-terminal domain of ice nucleation protein InaV. J Microbiol Biotechnol 22(2):234-238

Knudsen SM, Karlström OH (1991) Development of efficient suicide mechanisms for biological containment of bacteria. Appl Environ Microbiol 57(1):85-92

Lan WS, Gu JD, Zhang JL, Shen BC, Jiang H, Mulchandani A, Chen W, Qiao CL (2006) Coexpression of two detoxifying pesticide-degrading enzymes 
in a genetically engineered bacterium. Int Biodeterior Biodegrad 58(2):70-76

Larrainzar E, O'Gara F, Morrissey JP (2005) Applications of autofluorescent proteins for in situ studies in microbial ecology. Annu Rev Microbiol 59:257-277

Leff LG, Leff AA (1996) Use of green fluorescent protein to monitor survival of genetically engineered bacteria in aquatic environments. Appl Environ Microbiol 62(9):3486-3488

Li Q, Wu YJ (2009) A fluorescent genetically engineered microorganism that degrades organophosphates and commits suicide when required. Appl Microbiol Biotechnol 82:749-756

Matheson VG, Munakata-Marr J, Hopkins GD, McCarty PL, Tiedje JM, Forney LJ (1997) A novel means to develop strain-specific DNA probes for detecting bacteria in the environment. Appl Environ Microbiol 63(7):2863-2869

Mouches C, Pauplin Y, Agarwal M, Lemieux L, Herzog M, Abadon M, BeyssatArnaouty V, Hyrien O, de Saint Vincent BR, Georghiou GP (1990) Characterization of amplification core and esterase $\mathrm{B} 1$ gene responsible for insecticide resistance in Culex. Proc Natl Acad Sci USA 87(7):2574-2578

Nishi K, Huang H, Kamita SG, Kim IH, Morisseau C, Hammock BD (2006) Characterization of pyrethroid hydrolysis by the human liver carboxylesterases hCE-1 and hCE-2. Arch Biochem Biophys 445(1):115-123

Ramos-González MI, Ruiz-Cabello F, Brettar I, Garrido F, Ramos JL (1992) Tracking genetically engineered bacteria: monoclonal antibodies against surface determinants of the soil bacterium Pseudomonas putida 2440. J Bacteriol 174(9):2978-2985

Reimer AP, Prokopy LS (2012) Environmental attitudes and drift reduction behavior among commercial pesticide applicators in a US agricultural landscape. J Environ Manage 113:361-369

Ripp S, Nivens DE, Werner C, Sayler GS (2000) Bioluminescent mostprobable-number monitoring of a genetically engineered bacterium during a long-term contained field release. Appl Microbiol Biotechnol 53(6):736-741

Sambrook J, Russell DW (2001) Molecular cloning: a laboratory manual, 3rd edn. Cold Spring Harbor Laboratory Press, New York

Shimomura O, Johnson FH, Saiga Y (1962) Extraction, purification and properties of aequorin, a bioluminescent protein from luminous hydromedusan, Aequorea. J Cell Comp Physiol 59:223-239
Szafranski P, Mello CM, Sano T, Smith CL, Kaplan DL, Cantor CR (1997) A new approach for containment of microorganisms: dual control of streptavidin expression by antisense RNA and the T7 transcription system. Proc Natl Acad Sci USA 94(4):1059-1063

United States Agency for Toxic Substances and Disease Registry (1997) Toxicological profile for chlorpyrifos. https://www.atsdr.cdc.gov/toxprofiles/ tp84.pdf. Accessed Jan 2020

United States Environmental Protection Agency (1987). Permethrin. https:// cfpub.epa.gov/ncea/iris2/chemicallanding.cfm?substance_nmbr=185. Accessed Jan 2020

United States Environmental Protection Agency (1994). Danitol. https:// cfpub.epa.gov/ncea/iris2/chemicalLanding.ffm?substance_nmbr=34. Accessed Jan 2020

Vontas JG, Small GJ, Hemingway J (2000) Comparison of esterase gene amplifcation, gene expression and esterase activity in insecticide susceptible and resistant strains of the brown planthopper, Nilaparvata lugens (Stål). Insect Mol Biol 9(6):655-660

Wu CF, Cha HJ, Rao G, Valdes JJ, Bentley WE (2000) A green fluorescent protein fusion strategy for monitoring the expression, cellular location, and separation of biologically active organophosphorus hydrolase. Appl Microbiol Biotechnol 54(1):78-83

Wu J, Luan T, Lan C, Lo TWH, Chan GYS (2007) Removal of residual pesticides on vegetable using ozonated water. Food Control 18(5):466-472

Yurtkuran Z, Saygı Y (2013) Assessment of pesticide residues in karaboğaz lake from kızlırmak delta, Turkey. Bull Environ Contam Toxicol 91(2):165-170

Zhang WJ, Jiang FB, Ou JF (2011) Global pesticide consumption and pollution: with China as a focus. Proc Int Acad Ecol Environ Sci 1(2):125-144

\section{Publisher's Note}

Springer Nature remains neutral with regard to jurisdictional claims in published maps and institutional affiliations.

\section{Submit your manuscript to a SpringerOpen ${ }^{\circ}$ journal and benefit from:}

- Convenient online submission

- Rigorous peer review

- Open access: articles freely available online

- High visibility within the field

- Retaining the copyright to your article

Submit your next manuscript at $\boldsymbol{\nabla}$ springeropen.com 